\title{
Pengaruh Implementasi Sertifikasi SVLK, Karakteristik Produk dan Tujuan Ekspor Terhadap Harga Premium Ekspor Kayu Olahan Indonesia
}

\author{
Aditya Rahman Aziz 1, Vid Adrisson ${ }^{2}$ \\ 1) SBU Perdagangan Industri \& Kelautan PT Sucofindo (Persero) \\ 2) Fakultas Ekonomi dan Bisnis Universitas Indonesia \\ email: aditdot@gmail.com
}

\begin{abstract}
Abstrak
Harga premium merupakan indikator efektifitas pasar skema sertifikasi. Namun keberadaanya bergantung pada eco-consumer di negara tujuan ekspor. Penerapan sertifikasi idealnya sejalan dengan benefit yang diperoleh dari pasar. Riset ini bertujuan menganalisis apakah sertifikasi SVLK mampu memunculkan harga premium atas ekspor produk kayu olahan Indonesia serta melihat apakah terdapat pengaruh yang berbeda antara tujuan ekspor EU dan Non-EU. Analisis menggunakan data transaksional ekspor kayu olahan tahun 2006 - 2017 dengan menggunakan pendekatan hedonic model. Hasil analisis menunjukkan bahwa skema sertifikasi SVLK dapat memunculkan harga premium. Harga ekspor produk kayu olahan bersertifikat SVLK 7\% lebih mahal dibanding produk sejenis non-sertifikat. Namun demikian tidak terdapat pengaruh yang signifikan atas tujuan ekspor ke wilayah EU maupun Non-EU terhadap harga ekspor kayu olahan Indonesia.
\end{abstract}

Keywords: SVLK; ekspor; premium price; eco-consumer; kayu olahan

\begin{abstract}
Premium price is an indicator of certification market effectiveness. But its existence depends on the eco-consumers in the markets. Ideally, certification is in line with benefits obtained from the market. This research aims to analyze whether the SVLK certification is capable to generate premium price of Indonesian mouldings exports and see if there is a different effect between EU and Non-EU export destinations. The analysis base on transactional exports data from 2006 to 2017 using the hedonic model approach. The regression results show that the price of SVLK certified products is $7 \%$ more expensive than non-certificate products. However, there is no significant influence of the export destination to EU or Non-EU to the prices.
\end{abstract}

Keywords: SVLK; exports; premium price; eco-consumer; mouldings 


\section{PENDAHULUAN}

Pengaruh sertifikasi terhadap harga premium atas produk ekolabel masih menjadi isu penting dalam lingkup perdagangan internasional. Sertifikasi ekolabel sejatinya merupakan mekanisme penjaminan yang memiliki manfaat secara ekonomi. Tujuan dari program sertifikasi ekolabel adalah untuk menciptakan insentif berbasis pasar atas pengelolaan lingkungan yang lebih baik. Keberadaan konsumen yang membayar harga premium atas produk berlabel ramah lingkungan merupakan indikator efektifitas pasar dari skema ekolabel (Roheim, Asche dan Santos, 2011). Aguilar dan Vlosky (2007) menyatakan adanya hubungan yang kuat antara probabilitas kemauan untuk membayar harga premium dengan keberadaan konsumen yang memang secara khusus mencari produk bersertifikat dan meyakini bahwa sertifikasi akan dapat mengurangi deforestasi.

Hasil riset sebelumnya terkait pengaruh sertifikasi terhadap harga premium banyak berbasis pada konsep Willingnes to Pay (WTP) yang menunjukan adanya peningkatan preferensi konsumen akan produk bersertifikat. Penambahan WTP atas produk ekolabel di Amerika Serikat diestimasi sebesar 5\% - 18\% (Ozanne dan Vlosky, 1997; Aguilar dan Cai, 2010). Sedangkan untuk wilayah Eropa penambahan WTP berkisar antara 5\% sampai 10\% (Veisten, 2002; Aguilar dan Vlosky, 2007). Yamamoto, Takeuchi dan Shinkuma (2014) meringkas besaran estimasi penambahan WTP untuk produk kayu bersertifikat di wilayah Amerika Utara, Canada dan Eropa berkisar antara 1,4 \% sampai dengan $18.7 \%$. Sementara studi menggunakan data transaksi lelang kayu bulat di Jepang juga menunjukkan adanya kenaikan harga kayu bulat bersertifikat sebesar $1,4 \%$ dibanding kayu bulat non sertifikat (Yamamoto, Takeuchi, \& Shinkuma, 2014). Berbagai hasil riset tersebut menemukan bahwa terdapat hubungan positif sebagai potensi keberadaan harga premium atas produk berlabel ramah lingkungan sekaligus menunjukkan keberadaan masyarakat ecoconsumer di pasar Jepang, AS dan Uni Eropa.

Meskipun sebagian besar riset dilakukan dalam pasar domestik, namun tidak secara eksplisit menyebutkan atau membedakan asal dari produk yang bersertifikat ekolabel tersebut apakah dari lokal ataukah produk impor. Sehingga efek dari peningkatan WTP itu berlaku baik untuk produk bersertifikat secara umum termasuk produk yang berasal dari Impor.

Klaim penambahan WTP atas produk bersertifikat berdasarkan stated survey berpotensi berbeda dengan kondisi nyata. Kecenderungan konsumen responden untuk melebih-lebihkan atau overstatement serta adanya gap antara willingness to pay dan willingness to accept mempengaruhi bias yang terjadi. Hasil studi terdahulu mengemukakan adanya bias atau perbedaan antara keinginan untuk membayar yang dinyatakan (stated willingness to pay) dengan perilaku aktual (List dan Gallet, 2001; Murphy et al., 2005; Yamamoto, Takeuchi dan Shinkuma, 2014). Hasil survey kualitatif terhadap eksportir produsen kayu bersertifikat di Finlandia mengkonfirmasi bahwa status sertifikasi tidak selalu digunakan dalam aktifitas marketing, pemberian label dilakukan hanya jika diperlukan konsumen sehingga price premium tidak mungkin diterapkan oleh sebagian besar perusahaan yang bersertifikat (Owari, Juslin, Rummukainen, \& Yoshimura, 2006). Meskipun sertifikasi berkontribusi pada reputasi perusahaan sebagai respon atas tekanan pasar, namun secara umum tidak membantu meningkatkan kinerja keuangan perusahaan.

Indonesia memiliki kebijakan khusus terkait ekspor produk hasil hutan. Pemerintah Indonesia saat ini menerapkan kewajiban sertifikasi bagi seluruh ekspor produk perkayuan. Pada tahun 2010 Indonesia mulai menerapkan skema sertifikasi Sistem Verifikasi Legalitas Kayu (SVLK) secara bertahap. Periode tahun 2010 2012 merupakan periode penerapan secara voluntary untuk produk kayu olahan. Pemerintah memberlakukan SVLK secara mandatory untuk produk kayu olahan sejak Januari Tahun 2013. Praktis seluruh ekspor kayu olahan ketujuan manapun harus dilampiri dokumen V-legal sebagai turunan dari sertifikasi SVLK. Implementasi SVLK secara penuh atas seluruh komoditi kayu baru berjalan pada tahun 2016. Meskipun skema ini awalnya didesain untuk pasar Uni Eropa namun pemerintah Indonesia menetapkan kewajiban sertifikasi secara mandatory untuk seluruh produk ekspor kayu Indonesia. 
Skema sertifikasi apapun bentuknya memberikan konsekuensi berupa penambahan biaya bagi produsen. Penambahan biaya tersebut terkait dengan pengeluaran untuk pembangunan dan pengelolaan dari sistem yang dipersyaratkan disamping biaya sertifikasi itu sendiri. Pengelolaan sistem kemamputelusuran (Chain of Custody) untuk dapat memastikan bahwa aliran produk yang bersertifikat tidak terkontaminasi produk yang tidak bersertifikat membutuhkan biaya (Sedjo \& Swallow, 2002). Biaya pemenuhan standar bervariasi tergantung pada kondisi manajemen perusahaan, kompleksitas alur produksi dan kapasitas produksi. Penelitian oleh Astana et al (2014) atas biaya pelaksanaan sertifikasi SVLK dan FSC pada industri perkayuan kapasitas 2.000 dan $6.000 \mathrm{~m}^{3}$ per tahun mencapai USD 12.500 untuk skema SVLK dan USD 13.021 untuk skema FSC. Besaran biaya ini setara dengan USD 5,2 - 15,6 per meter kubik (SVLK) serta USD $5,4-16,3$ (FSC) bergantung pada unit produksi yang dihasilkan. Semakin kompleks alur produksi dengan kapasitas produksi yang besar dapat dikenakan biaya sertifikasi yang tinggi namun biaya per unitnya yang lebih rendah.

Insentif pasar akan sangat bergantung pada pengakuan pasar internasional atas kredibilitas skema sertifikasi. Idealnya, besaran biaya yang dikeluarkan selama masa persiapan dan proses sertifikasi akan dapat terkompensasi dengan adanya differensiasi harga produk kayu bersertifikat yang juga menunjukkan adanya eco-consumers di pasar tujuan ekspor. Namun demikian, untuk skema sertifikasi yang sifatnya mandatory pada kondisi apabila seluruh eksportir telah bersertifikat atau tidak terdapat eco-consumers di Negara tujuan ekspor, maka harga premium mungkin dapat tidak terbentuk pada pasar. Kebijakan penerapan SVLK pada seluruh negara tujuan ekspor memiliki potensi mendapatkan price premium atas produk jika di negara tujuan terdapat eco-consumers. Namun apabila ternyata tidak terdapat ecoconsumer di negara tujuan maka price premium dapat tidak terbentuk, meskipun secara biaya terkait sertifikasi tetap harus dikeluarkan oleh ekspotir atau produsen.

Belum jelasnya pengaruh dari sertifikasi SVLK terhadap keberadaan harga premium produk ekspor kayu Indonesia merupakan alasan yang mendasari penelitian ini. Tujuan utama dari riset ini adalah menganalisis pengaruh sertifikasi Legalitas Kayu (SVLK) terhadap pembentukan harga premium ekspor produk kayu olahan Indonesia. Selain itu riset ini juga akan menganalisis apakah terdapat pengaruh yang berbeda atas penerapan sertifikasi terhadap negara tujuan ekspor Uni eropa dan Non-Uni Eropa, mengingat implementasi SVLK saat ini diberlakukan secara mandatory.

Pemberian label pada produk ekolabel menjadikan ciri atau karakteristik khusus yang melekat pada produk. Apabila terdapat konsumen yang memiliki preferensi khusus terhadap produk dengan karakteristik ramah lingkungan dan peduli kelestarian (ecoconsumers), maka kondisi ini akan mendorong terjadinya price differential dari produk ekolabel tersebut. Harga premium yang pada pasar ekspor dapat tergantung pada mekanisme transmisi harga yang menunjukkan kompensasi dari jenis bahan baku dan tingkat produksi. Karena fokus analisis adalah pada nilai marjinal dari karakteristik sertifikasi berupa harga premium, maka pada riset ini mengikuti apa yang digagas oleh Rosen (1974) dan menggunakan model harga hedonis untuk menentukan ada atau tidaknya price premium pada ekspor kayu olahan Indonesia. Karena karakteristik produk perkayuan akan berpengatuh terhadap harga maka pada riset ini akan menyertakan variable-variable karakteristik produk perkayuan sebagai kontrol.

\section{TINJAUAN LITERATUR \\ Teori Hedonic Model}

Hedonic model merupakan salah satu metode penentuan nilai produk mendasarkan pada karakteristik yang dimilikinya. Landasan teoretis untuk permodelan hedonic pertama kali dikemukakan oleh Lancaster (1966) yang berpendapat bahwa suatu produk tidaklah membentuk utilitasnya sendiri tetapi karakteristik yang ada pada produk tersebutlah yang membentuk utilitas. Sehingga utilitas suatu produk merupakan agregasi dari utilitas individual dari tiap karakteristik. Karakteristik suatu produk inilah yang mempengaruhi keputusan konsumen untuk mengkonsumsi suatu barang sebagai bentuk dari preferensi konsumen. 
Utilitas yang diperoleh konsumen adalah subjektif dan tergantung pada fungsi preferensi. Sehingga meskipun suatu barang memiliki sifat fisik yang sama, karena subyektifitas dari konsumen dapat memiliki harga yang berbeda. Kondisi inilah yang dapat menjelaskan kenapa keberadaan konsumen yang memiliki utilitas terhadap barang bersertifikat akan bersedia membeli harga lebih tinggi.

Penggunaan hedonic model dalam penetapan harga suatu produk baru dikembangkan oleh Rosen (1974) yang dikenal sebagai hedonic pricing model. Penentuan nilai suatu barang dapat melalui mekanisme penjumlahan dari karakteristik yang membangkitkan utilitas. Sehingga harga produk seharusnya merupakan penjumlahan dari harga individual dari karakteristik yang ada pada suatu produk (Rosen, 1974). Kondisi ini memungkinkan untuk meregresikan harga atas karakteristik yang dimiliki untuk menentukan cara setiap karakteristik berkontribusi terhadap harga suatu produk dengan mengetahui nilai marginal implisitnya. Untuk mengestimasi model yang menjelaskan nilai suatu karakteristik di pasar, vektor nilai marginal implisit diperoleh dengan mendifferensiasikan harga $P$ (Z) dengan argumennya $\mathrm{Zi}$.

$$
\begin{aligned}
& P=f\left(Z_{i}\right) \\
& P_{i}=\delta P(Z) / \delta\left(Z_{i}\right) \\
& P=f\left(Z_{1}, Z_{2}, Z_{3}, \ldots . Z_{n}\right) \\
& P=X \beta+\varepsilon
\end{aligned}
$$

Dimana $P$ adalah harga barang, $Z_{i}$ adalah karakteristik yang melekat pada produk dan $P_{i}$ adalah nilai marginal dari karakteristik. Sehingga dengan konsep ini dapat diketahui pengaruh yang terjadi pada harga saat terjadi perubahan kualitas dari karakter suatu produk. Untuk memudahkan notasi, dalam penulisan digunakan matriks $X$ untuk merepresentasikan kombinasi dari masing-masing vektor $Z_{1}, Z_{2}, Z_{3}$ dan $Z_{n}$. Sehingga harga yang diharapkan dari suatu produk adalah karakteristik $X$ dikalikan $\beta$, di mana $\beta$ mewakili vektor dari harga marjinal.

Selain itu Hedonic model dapat digunakan dalam fungsi non-linear dimana dalam hal ini, log dari harga yang diharapkan suatu item adalah jumlah dari karakteristiknya $X$ dikalikan $\beta$, dan harga marjinal dari setiap atribut individual $x$ adalah:

$$
\text { lnPrice }=X \beta+\varepsilon
$$$$
\operatorname{Price}(x)=e^{x \beta}
$$

Dimana $x$ adalah current level dari karakteristik dan $b$ adalah koefisien regresi. Model hedonik log-linear memiliki beberapa keunggulan yaitu memungkinkan nilai karakteristik tertentu untuk bervariasi secara proporsional dengan nilai karakteristik lain. Selain tu fungsi bentuk loglinear juga dapat diinterpretasikan dengan mudah, dimana parameter yang diestimasi dinyatakan dalam persentase (Roheim, Asche dan Santos, 2011).

\section{Teori Permintaan dan Penawaran}

Secara teoretis permintaan dan penawaran terhadap suatu produk akan mempengaruhi besaran ekspor maupun impor. Dalam teori perdagangan internasional faktor-faktor yang dapat mempengaruhi ekspor dapat dilihat dari sisi permintaan dan penawaran (Krugman dan Obsfeld, 2000). Kurva permintaan pasar empiris atau aktual untuk suatu komoditi dapat diperkirakan melalui data pasar mengenai jumlah pembelian komoditi itu pada berbagai harga sepanjang waktu (Salvatore, 2007). Cita rasa, preferensi, pendapatan maupun harga dari suatu produk dapat berubah dari waktu ke waktu kondisi ini akan mempengaruhi pergeseran (shifting) pada sisi permintaan. Demikian halnya dari sisi penawaran, untuk dapat memenuhi memenuhi kebutuhan pasar, maka faktor-faktor produksi akan menyesuaikan pasar, hal ini akan mendorong terjadinya pergeseran dari sisi penawaran.

supply dan demand dalam ranah perdagangan internasional akan dipengaruhi oleh supply demand domestik dan supply demand dari negara importir. Pada dasarnya terdapat dua pasar di dunia yaitu pasar untuk produk bersertifikat dan pasar untuk produk yang tidak bersertifikat. Kedua pasar memiliki tingkat harga yang berbeda, harga produk bersertifikat (Ps) lebih tinggi dibandingkan produk non sertifikat (Pns). 


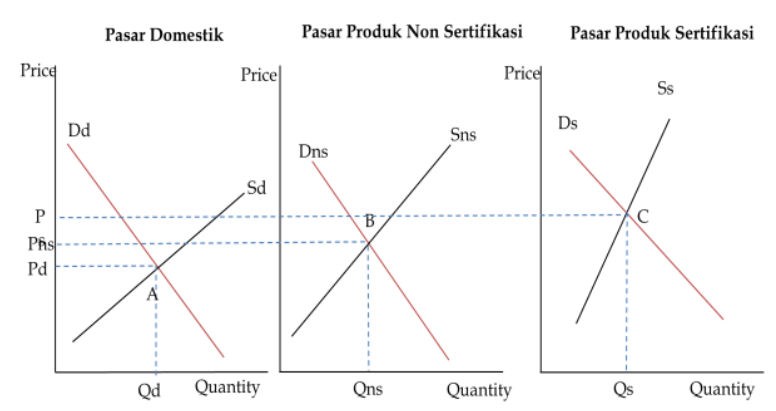

\section{Gambar 1 Kurva supply demand produk ekspor sebelum sertifikasi}

Pada periode awal sebelum penerapan sertifikasi konsentrasi ekspor dari produk kayu olahan hanya ditujukan pada pasar non sertifikasi dengan tingkat harga (Pns) dan Quantity (Qns). Ekspor produk kayu olahan sebesar (a) terjadi saat Pns > Pd dengan asumsi bahwa harga ekspor adalah sama dengan harga produk di luar negeri. Meskipun terdapat pasar dengan tingkat harga yang lebih tinggi (Ps) namun produk ekspor domestik belum dapat masuk karena belum tersertifikasi.

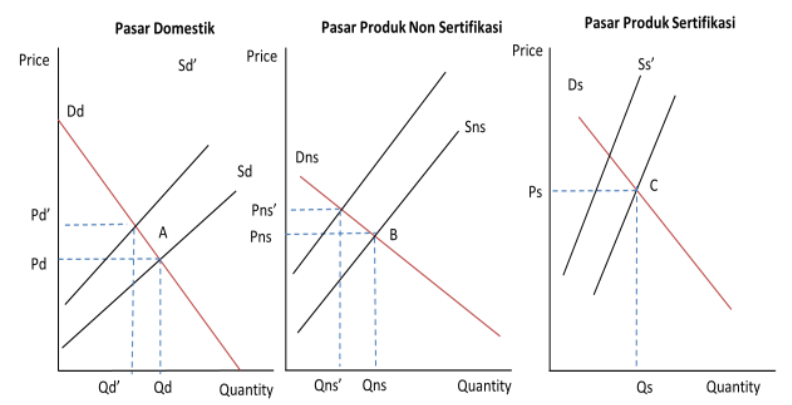

\section{Gambar 2 Kurva supply demand produk ekspor setelah sertifikasi}

Sertifikasi merupakan prasyarat agar dapat masuk ke pasar produk bersertifikat yang memiliki tingkat harga yang lebih baik. Price premium pada konteks ini didefinisikan sebagai selisih harga antara harga produk bersertifikat dengan harga produk bersertifikat. Saat pasar domestik menerapkan sertifikasi maka proses ini berkonsekuensi pada naiknya biaya produksi kayu olahan. Saat biaya produksi naik maka marginal cost (mc) produksi kayu olahan meningkat, hal ini mendorong terjadinya shifting kurva supply pasar domestik dari Sd ke Sd'. Pergeseran kurva supply domestik ini mengakibatkan terjadinya kenaikan harga domestik ( $\mathrm{Pd}$ ke Pd') dan penurunan jumlah produksi kayu olahan (Qd ke Qd'). Jika share ekspor kayu olahan pasar domestik cukup besar di dunia maka pengurangan produksi kayu olahan domestik berpengaruh pada supply demand dunia. Namun jika sebaliknya maka pengurangan produksi domestic tidak akan berpengaruh pada supply demand dunia.

Jika penerapan sertifikasi secara voluntary maka pengaruh dari perubahan supply domestik tidak akan berpengaruh besar pada supply dunia. Karena sifatnya yang voluntary maka pada pasar dunia masih terdapat supply produk bersertifikat dan produk bersertifikat. Karena sifatya yang voluntary maka sertifikasi ini hanya akan dijalankan oleh produsen yang memang membutuhkan atau yang memang telah memiliki market di pasar produk sertifikasi dan sharenya relatif kecil jika dibandingkan produk dunia. Sehingga pada periode ini pasar dunia tidak mengalami berubahan sebagai akibat dari perubahan supply di pasar domestik. Sementara di sisi lain sebagaian produsen di pasar domestik telah dapat masuk ke pasar produk sertifikasi dengan tingkat harga Ps.

Penerapan sertifikasi secara mandatory akan memiliki konsekuensi yang berbeda. Sertifikasi secara mandatory artinya bahwa seluruh produk kayu olahan ekspor harus bersertifikasi. Sehingga secara umum efek terjadi kenaikan biaya produksi yang berdampak pada penurunan supply kayu olahan (bersertifikat). Jika suatu negara memiliki market yang besar alam pasar dunia, penerapan sertifikasi wajib akan mengakibatkan supply dunia bergeser ke kiri atas (Ss') sebagai akibat kenaikan biaya produksi domestik (akibat sertifikasi).

Namun jika sharenya kecil maka Ss tetap tidak bergeser dan harga produk bersertifikat tetap (Ps). Di sisi lain karena semua produk yang diekspor adalah produk bersertifikat maka kondisi ini akan mempengaruhi supply demand pada pasar produk non sertifikasi. Apabila market share besar maka kondisi ini akan signifikan mempengaruhi supply produk non sertifikat sehingga kurva Sns akan bergeser ke kiri Sns'. Shifting kurva supply di pasar non sertifikasi berdampak pada naiknya harga produk non sertifikasi pada pasar dunia. Sama halnya pada pasar produk bersertifikat jika kondisi market share kayu olahan kecil di pasar dunia maka kondisi ini tidak akan terjadi. 
Penerapan skema sertifikasi secara mandatory akan efektif pada pasar yang tepat. Karena seluruh produk wajib bersertifikat maka seluruh produsen mengalami penambahan biaya produksi. Sesuai grafik 2.2, pada pasar yang tepat maka kenaikan biaya ini akan dapat terkompensasi dengan tingkat harga produk yang lebih tinggi (Ps atau Ps') yang menunjukkan adanya eco-consumer pada negara tersebut. Namun apabila ternyata negara tujuan ekspor tidak memiliki ecoconsumer maka besaran kenaikan biaya produksi tersebut tidak akan terkompensasi, karena produk hanya akan menerima tingkat harga yang sama dengan produk non sertifikat pada tingkat harga Pns ataupun maksimal Pns'. Atas kondisi ini maka idealnya akan terjadi pergeseran tujuan ekspor ke negara-negara yang memiliki konsumen yang berpreferensi khusus pada produk bersertifikat.

\section{Kharakteristik Produk Perkayuan}

Karakteristik produk kayu sangat penting dalam perdagangannya. Sistem perdagangan kayu di pasar domestik maupun internasional mengacu kepada pengelompokan jenis kayu berdasarkan karakteristik umum yang dianggap penting dan dimiliki oleh kelompok jenis yang bersangkutan. Acuan karakteristik umum terutama dilihat dari segi penampilan atau dekoratif (appearance), berat jenis, dan keawetan (Boampong et al., 2015).

Saat ini dalam perdagangan produk kayu di Indonesia, jenis kayu dikelompokkan ke dalam empat kelompok utama. Kayu yang termasuk dalam Kelompok kayu indah merupakan kayu yang memiliki nilai keindahan, berat jenis, dan kelas awet tinggi contoh kayu untuk kelompok ini adalah kayu Eboni dan Jati. Jenis kayu kelompok Meranti merupakan jenis kayu yang memiliki nilai BJ dan kelas awet tinggi, namun keindahannya kurang. Sedangkan kelompok rimba campuran merupakan jenis-jenis kayu yang memiliki nilai berat jenis dan kelas awet sedang, sedangkan jenis kayu termasuk dalam kelompok Kelas Komersial III dengan nilai BJ dan kelas awet rendah contoh kayu sengon (Balfas, 2016).

Merujuk pada praktek perdagangan yang ada, bahwa bahan baku kayu tidak hanya berasal dari dalam negeri. Pada beberapa produk kayu menggunakan bahan baku yang berasal dari kayu impor seperti halnya kayu Cyprus, Oaks, Walnut dan sejenisnya. Hal ini dilakukan industry perkayuan untuk memenuhi spesifikasi yang telah ditentukan dari buyer biasanya untuk kepentingan dekoratif atau untuk menyesuaikan kondisi iklim dimana produk kayu tersebut akan digunakan. Oleh karena ini dalam penelitian ini ditambahkan satu kelompok kayu impor.

\section{Sertifikasi Legalitas Kayu SVLK}

Sistem Verifikasi Legalitas Kayu (SVLK) adalah salah satu inisiatif yang muncul untuk mengatasai pembalakan liar dan mempromosikan kayu legal di Indonesia. Secara khusus, sistem ini bertujuan untuk memastikan bahwa kayu dan produk kayu yang diproduksi di Indonesia berasal dari sumber-sumber yang legal yang dapat diverifikasi dan dikelola secara lestari. SVLK diterapkan secara bertahap untuk meningkatkan efisiensi pengelolaan hutan dan menjaga kredibilitas legalitas kayu dari Indonesia dan mulai berlaku sejak 1 September 2009 dan secara penuh berlaku secara mandatory pada 1 Januari 2013 yang ditandai dengan wajib penyantuman dokumen V-Legal di setiap ekspor produk perkayuan. V-legal dokumen sendiri hanya dapat dicantumkan apabila perusahaan telah bersertifikat SVLK. Sehingga periode September 2009 sampai dengan Desember 2012 sertifikasi SVLK ini masih bersifat Voluntary.

Kayu disebut legal jika kebenaran asal kayu, ijin penebangan, system dan prosedur penebangan, administrasi dan dokumentasi angkutan, pengolahan, dan perdagangan atau pemindahtangannya dapat dibuktikan memenuhi semua persyaratan serta sesuai dengan peraturan perundangan yang berlaku di Indonesia. Lingkup sertifikasi SVLK berkesinambungan dari hulu (hutan) sebagai sumber bahan baku sampai dengan Industri Perkayuan. Peraturan untuk pendistribusian maupun pengolahan bagi masing masing tahapan juga berbeda dan diatur secara terperinci. Atas kondisi tersebut standar prinsip, kriteria dan indikator yang ada di SVLK merujuk pada seluruh peraturan yang berlaku, baik lingkup perijinan di sektor kehutanan, perindustrian, perdagangan, lingkungan, maupun ketenagakerjaan. Sebagai 
konsekuensi dari aspek legalitas maka seluruh ketentuan dalam standar harus dipenuhi, satu kriteria tidak terpenuhi maka sertifikasi legalitas tidak dapat diberikan.

Atas perusahaan yang lulus sertifikasi berhak untuk mencantumkan logo Verified Legal dalam produk maupun dokumen perdagangan. Logo sertifikat inilah yang merupakan perangkat pemasaran yang diperuntukan bagi konsumen untuk dapat membedakan produk kayu mana yang legal dan diproduksi dengan memperhatikan aspek lingkungan.

Mekanisme sertifikasi legalitas kayu terdiri atas dua aspek penjaminan yaitu penjaminan atas system pengelolaan kayu yang legal dan traceable serta penjaminan produk kayu yang legal melalui mekanisme penerbitan dokumen verified legal ( $v$-legal) yang mengikuti produk kayu sampai ke negara tujuan ekspor. Dokumen v-legal melekat pada tiap produk kayu yang diekspor ini terintegrasi dengan system Indonesian National Single Window (INSW) dan berlaku sebagai salah satu dokumen persyaratan ekspor. Informasi terkait aktifitas sertifikasi VLK ataupun penerbitan VLegal terintegrasi pada Licensed Information Unit dibawah Kementerian Kehutanan. Seluruh ekspor produk yang masuk ke dalam kode HS 4407 dan 4409 wajib berlisensi V-legal sejak 1 Januari 2013. Dokumen V-Legal ini yang digunakan sebagai clearance serta mengikuti barang yang diekspor sampai ke negara tujuan untuk menerangkan bahwa produk tersebut berasal dari sumber yang legal yang mampu tertelusur.

\section{Sertifikasi Skema Forestry Stewardship Council (FSC)}

Forest Stewardship Council (FSC) adalah lembaga international non-profit merupakan Lembaga Akreditasi yang pertama kali mengembangkan dua sistem sertifikasi yang utama, yaitu Sertifikasi Pengelolaan Hutan (Forest Management), Sertifikasi Lacak Balak (Chain of Custody). Masing-masing sistem sertifikasi berkembang sesuai kebutuhan akan kondisi hutan dan pasar. Sampai dengan saat ini lebih dari 30 juta ha areal hutan di berbagai belahan penjuru dunia telah disertifikasi oleh lembaga sertifikasi yang telah diakreditasi oleh FSC. Sertifikasi FSC merupakan skema sertifikasi voluntary yang memiliki standar dan proses sertifikasi yang cukup ketat namun mendapat pengakuan yang sangat signifikan dari berbagai stakeholder di tingkat international.

Sertifikasi Chain of Custody (COC) merupakan skema sertifikasi FSC yang berlaku untuk produsen, manufaktur, dan pedagang hasil hutan bersertifikat FSC. Chain of Custody memastikan bahan baku produk berasal dari sumber/hutan yang bersertifikat FSC dan proses produksi di sepanjang rantai supply tidak tercampur bahan baku lain yang tidak bersertifikat, kecuali Controlled Wood. Perusahaan yang telah tersertifikasi dengan skema ini akan mendapatkan sebuah sertifikat dan dapat menggunakan logo FSC pada produknya. Dalam strata skema COC, ada tiga pilihan yang dapat diterapkan, yaitu FSC Pure (100\%), FSC Mixed (bahan bakunya campuran dari FSC dan Controlled Wood) dan FSC Recycled (bahan baku dari bekas/daur ulang). FSC Controlled Wood dikembangkan agar perusahaan/manufaktur yang belum bersertifikat FSC tidak mengambil kayu dari sumber yang tidak diterima (unacceptable). Kayu bersertifikat Chain of Custody hanya dapat dicampur dengan FSC Controlled Wood, untuk produk berlabel FSC Mixed.

\section{GDP Perkapita, Jarak dan Nilai Tukar}

Pada dasarnya terbentuknya price premium produk bersertifikat akan bergantung pada keberadaan konsumen yang memiliki preferensi khusus pada produk bersertifikat. Konsumen dengan preferensi khusus ini akan sangat tergantung pada masyarakat yang memiliki tingkat pendapatan (income) yang tinggi. Sehingga dalam konteks ekspor akan ada hubungan yang kuat antara pasar produk bersertifikat dengan income percapita dari Negara tujuan.

Keputusan konsumsi akan dipengaruhi oleh besaran pendapatan atau income. Aguilar dan Vlosky (2007) mengkonfirmasi bahwa terdapat hubungan kuat antara income dan price premium dimana semakin tinggi tingkat kemakmuran suatu pasar, maka konsumen existing sudah terbiasa dengan adanya price differential antara produk ekolabel dan nonekolabel. Oleh karena itu untuk dapat menghubungkan antara data transaksional dengan konsumsi rumah tangga negara tujuan 
ekspor, dalam penelitian ini ditambahkan variable control GDP perkapita negara tujuan ekspor.

Prestemon (2015) menyatakan bahwa terdapat efek permanen ataupun transitory dari nilai tukar yang dapat mempengaruhi harga dan jumlah ekspor untuk menyesuaikan kebijakan sertifikasi, terutama jika nilai tukar berubah secara signifikan selama rentang waktu yang dimodelkan. Untuk mengantisipasi kondisi tersebut maka dalam model persamaan variable nilai tukar rupiah terhadap mata vang negara tujuan ekspor digunakan sebagai control variabel.

Jarak merupakan proksi untuk biaya transportasi. Krugman (2009) menyatakan bahwa jarak antara dua negara menjadi determinan penting dalam pola perdagangan secara geografis, karena jarak dapat meningkatkan biaya transportasi, meskipun jarak bukan satu-satunya biaya yang harus ditanggung.

\section{METODOLOGI}

\section{Jenis dan Sumber Data}

Tujuan dari analisis ini adalah mengetahui pengaruh sertifikasi Legalitas Kayu (SVLK) terhadap pembentukan harga premium ekspor produk kayu olahan Indonesia. Untuk memperoleh hasil yang mendekati pasar maka dalam riset ini digunakan data transaksional ekspor. Data yang digunakan adalah data transaksional ekspor kayu olahan HS 4407 dan 4409 periode Maret 2006 - Maret 2017. Data transaksional ekspor diperoleh dari data Verifikasi Ekspor Produk Industri Kehutanan berupa rekapitulasi data Laporan Surveyor (LS) PT. SUCOFINDO (Persero) sejumlah 189.804 data observasi. Laporan Surveyor merupakan salah satu dokumen kepabeanan atas produkproduk kayu yang dikenai pembatasan kriteria teknis untuk dapat diekspor ke luar negeri. Data yang diperoleh mencakup informasi eksportir, tanggal ekspor, nilai FOB, besaran volume, jenis kayu, nomor HS, tipe kayu (solid dan engineering) dan Negara tujuan ekspor.

Untuk mengetahui pengaruh dari sertifikasi memerlukan berbagai data sebagai variabelvariabel yang dapat mempengaruhi harga. Variabel utama dalam riset ini adalah variable harga ekspor per meterkubik produk olahan
Indonesia sebagai dependent variable. Sedangkan variable kontrol akan mencakup variable status sertifikasi, kharakteristik produk, tujuan ekspor, sertifikasi pembanding (FSC) serta variable lain yang mempengaruhi perdagangan antar negara (GDP perkapita jarak dan nilai tukar).

Data status sertifikasi ini penting terkait dengan informasi kapan eksportir bersertifikat. Data status sertifikasi ini merujuk pada publikasi dari lembaga Sertifikasi Legalitas Kayu, data publikasi dari Jaring Pemantau Independen Kehutanan (JPIK) dan data publikasi Sistem Informasi Legalitas Kayu (SILK) Kementerian Lingkungan Hidup dan Kehutanan. Sedangkan variable-variabel control yang digunakan dalam riset ini bersumber dari:

1) data status kepemilikan sertifikasi lainnya (FSC), yang merujuk pada publikasi website Forestry Stewardship Council (FSC) www.fsc.org;

2) data nilai tukar rupiah terhadap dollar menggunakan rilis data dari IMF;

3) data jarak Indonesia dengan negara tujuan ekspor menggunakan data rilis website http://indonesia.distanceworld.com dan pengolahan data menggunakan aplikasi google earth;

4) data GDP perkapita negara tujuan ekspor menggunakan rilis data dari IMF;

\section{Pengolahan Data}

Tahapan awal dalam analisis ini adalah melakukan pengelompokan dan agregasi data data transaksional ekspor produk kayu HS 4407 dan 4409. Pengelompokan dan agregasi ini untuk memperoleh id crossection yang konsisten berdsarkan periode bulanan. Id crossection meliputi data nama eksportir, per negara tujuan, per HS (4407 dan 4409), per jenis kayu (indah, meranti, KRC dan impor), per tipe bahan baku (solid dan engineering) dan per status sertifikasi (SVLK dan FSC) yang dikelompokkan pada periode bulanan. Sehingga diperoleh data realisasi total volume, nilai FOB bulanan dan nilai/harga per meterkubik sesuai id crossection.

\section{Analisis Difference in Difference (DID)}

Analisis difference-in-difference merupakan suatu desain analisis yang menggunakan data 
longitudinal dari kelompok perlakuan dan kontrol untuk memperkirakan efek dari intervensi atau perlakuan khusus dengan membandingkan perubahan hasil dari waktu ke waktu antara kelompok intervensi dan kelompok kontrol. DID digunakan dalam kondisi dimana pertukaran tidak dapat diasumsikan antara kelompok perlakuan dan kelompok kontrol. DID bergantung pada asumsi pertukaran yang tidak terlalu ketat misalkan dengan ketiadaan treatment maka perbedaan antara kelompok intervensi dan kelompok kontrol adalah sama sepanjang waktu. Analisis ini memerlukan data sebelum maupun sesudah interensi baik dalam bentuk data panel maupun cross section. Pendekatan ini dilakukan untuk menghilangkan bias dalam perbandingan pasca intervensi antara kelompok intervensi dan kelompok kontrol yang dapat merupakan hasil dari perbedaan permanen dari kedua kelompok ataupun bias dari karena perlakuan antar waktu yang mungkin merupakan tren yang disebabkan oleh faktor lain.

Dalam penelitian ini terdapat dua periode waktu dalam implementasi sertifikasi SVLK yaitu periode voluntary $(2010$ - 2012) dan periode mandatory (2013 - 2017). Pengaruh dari sertifikasi akan mencakup pengaruh sertifikasi terhadap produk dan pengaruh pengerapan sertifikasi secara mandatory terhadap produk yang sebelumnya bersertifikat voluntary (khusus SVLK). Untuk dapat melihat pengaruh dari kedua kondisi tersebut dapat dimodelkan sebagai berikut:

$P=\alpha+\beta v t+\beta m+\beta v m+e$

Dimana:

vt : Dummy Variabel bernilai 1 jika transaksi ekspor merupakan produk yang bersertifikat dalam periode voluntary, bernilai 0 jika diluar kriteria tersebut;

m : Dummy Variabel transaksi ekspor produk yang bersertifikat dalam periode mandatory dimana $\mathrm{m}$ bernilai 1 jika produk bersertifikasi setelah tahun 2013 dan bernilai 0 jika diluar kriteria tersebut;

vm : Dummy variable atas produk yang telah bersertifikasi pada periode voluntary dan observasi setelah pemberlakukan mandatory. vm bernilai 1 jika produk pada pada periode mandatory telah bersertifikasi pada periode voluntary, bernilai 0 jika diluar kriteria tersebut.

Untuk dapat memperoleh pengaruh sebelum dan sesudah penerapan sertifikasi SVLK secara voluntary dirumuskan sebagaimana berikut:

$$
E\left(P_{v t=1}\right)-E\left(P_{v t=0}\right)=\beta v t
$$

Untuk dapat memperoleh pengaruh sebelum dan sesudah penerapan sertifikasi SVLK secara mandatory dirumuskan sebagaiman berikut:

$$
E\left(P_{m=1}\right)-E\left(P_{m=0}\right)=\beta m
$$

Untuk dapat memperoleh pengaruh sebelum dan sesudah penerapan sertifikasi mandatory atas produk yang sebelumnya telah bersertifikasi secara voluntary dirumuskan sebagaiman berikut:

$$
E\left(P_{v m=1}\right)-E\left(P_{v m=0}\right)=\beta v m
$$

\section{Analisis Data Panel}

Analisis data menggunakan analisis data panel memiliki beberapa kelebihan. Data panel mampu memberikan informasi yang lebih lengkap, tingkat variabilitas yang lebih tinggi, kolinearitas antar variabel berkurang, derajat bebas yang lebih banyak, dan lebih efisien. Penggabungan data time series dan cross section akan memberikan lebih banyak jumlah observarsi. Peningkatan jumlah observasi akan meningkatkan variabilitas dan informasi data sehingga mampu mengurangi koliniaritas antar variabel. Peningkatan tersebut juga akan meningkatkan derajat bebas yang pada akhirnya akan mampu menghasilkan estimasi yang lebih efisien.

Metode analisis panel data terdiri dari perumusan model, pemilihan metode estimasi, uji kriteria, dan analisis hasil estimasi. Model regresi yang digunakan dalam analisis data panel umumnya menggunakan tiga macam model yang terdiri dari Pooled Least Square, Fixed Effect Model, dan Random Effect Model. Untuk dapat menentukan model analisis data panel Fixed Effect Model atau Random Effect Model yang akan digunakan terlebih dahulu dilakukan uji Hausman.

\section{Herfindahl index}

Herfindahl Hirchman Index (HHI) merupakan metode untuk mengukur tingkat konsentrasi dari suatu pasar. HHI sering digunakan untuk mengkarakterisasi distribusi variabel yang diteliti 
dengan mengukur tingkat konsentrasinya di seluruh unit, seperti perusahaan, tim, atau rumah tangga (Owen, Ryan, \& Weatherston, 2007). Untuk mengukur distribusi pangsa pasar perusahaan dalam suatu industri itu $\mathrm{HHI}$ didefinisikan sebagai:

$$
H H I=\sum_{i=1}^{n}\left(M S_{i}\right)^{2}
$$

Dimana MSi adalah market share dari i firm dari suatu industry yang terdiri dari $n$ perusahaan.

Dalam penelitian ini penghitungan $\mathrm{HHI}$ dilakukan dengan menghitung market share dari eksportir kayu olahan Indonesia. Penghitungan marketshare menggunakan nilai ekspor FOB dari tiap eksportir untuk produk kayu yang dominan (cth. Produk kayu meranti solid) dalam rentang waktu 1 tahun, dihitung dengan menggunakan formulasi sebagaimana berikut:

$$
\begin{aligned}
& M S=\frac{\text { Jumlah nilai ekspor produk } \text { firm }_{i}}{\text { Total Nilai Ekspor Produk Kayu Olahan }} \\
& H H I=M S_{1}^{2}+M S_{2}^{2}+M S_{3}^{2}+\ldots+M S_{n}^{2}
\end{aligned}
$$

Rentang $\mathrm{HHI}$ dan indikasinya sebagaimana berikut:

1. Nilai HHI di bawah 0,01 (atau 100) menunjukkan industri dengan pasar yang sangat kompetitif.

2. H di bawah 0,15 (atau 1.500) menunjukkan industri dengan pasar yang tidak terkonsentrasi.

3. $\mathrm{H}$ antara 0,15 hingga 0,25 (atau 1.500 hingga 2.500) menunjukkan industry dengan tingkat konsentrasi sedang.

4. H di atas 0,25 (di atas 2.500) menunjukkan konsentrasi tinggi

\section{Model Penelitian}

Keberadaan Price premium akan teridentifikasi saat adanya differensiasi harga produk bersertifikat dengan produk non sertifikat di pasar. Price premium diasumsikan sebagai nilai marjinal dari sertifikasi terhadap harga. Untuk dapat mengukur fenomena tersebut riset ini menggunakan variabel dependen berupa harga per meter kubik kayu olahan HS 4407 \& 4409 (FOB) dalam bentuk logaritmik (InP).

Sedangkan variabel independen yang digunakan dalam study ini mencakup karakteristik yang melekat pada produk kayu olahan meliputi tingkat olahan, jenis kayu, jenis bahan baku, dan status sertifikasi serta variabel yang mempengaruhi perdagangan antar negara meliputi Tujuan negara, GDP perkapita, jarak antar negara dan nilai tukar. Khusus untuk variable sertifikasi digunakan tiga variable merujuk pada kapan sertifikasi diperoleh pada periode voluntary ataukah mandatory. Sehingga model awal untuk penelitian ini dapat dituliskan sebagai berikut:

$$
\begin{aligned}
& \mathrm{P}_{\mathrm{ijt}}=\mathrm{f}\left(\mathrm{SVLK}_{\mathrm{i}}, \text { SVLK_Mandatory }_{\mathrm{i}}, \mathrm{FSC}_{\mathrm{i}} \text {, JenisKayu } \mathrm{J}_{\mathrm{i}}\right. \text {, } \\
& \text { Tujuan }_{\mathrm{j}}, \operatorname{Jarak}_{\mathrm{j}}, \text { Kurs }_{\mathrm{t}}, \text { GDPCap }_{\mathrm{j}} \text { ) } \\
& P_{i j t}=\beta_{0}+\beta_{1} v t_{i}+\beta_{2} m_{i}+\beta_{3} F_{i}+\beta_{4} F v t_{i}+ \\
& \beta_{5} F m_{I}+\beta_{6} K_{-} I_{i}+\beta_{7} K_{-} M_{i}+\beta_{8} K R C_{i}+ \\
& \beta_{9} \text { Kom }_{i}+\beta_{10} K_{-} \text {Impor }_{i}+ \\
& \beta_{11} \text { KSolid }_{i}+\beta_{12} \text { nonE }_{j}+\quad \beta_{13} \text { Jarak }_{j}+ \\
& \beta_{14} \text { Kurs }_{t}+\beta_{15} \text { GDPcap }_{j}+ \\
& \beta_{15} \text { nonEU_GDPcap }{ }_{j}+e_{i j t}
\end{aligned}
$$

Model akan diestimasi dalam bentuk logaritma linear. Maka, persamaan yang diestimasi adalah sebagai berikut :

$$
\begin{aligned}
\operatorname{LnP}_{i j t}= & \beta_{0}+\beta_{1} v t_{i}+\beta_{2} m_{i}+\beta_{3} F_{i}+\beta_{4} F v t_{i}+ \\
& \beta_{5} F_{I}+\beta_{6} K_{-} I_{i}+\beta_{7} K_{-} M_{i}+\beta_{8} \text { KRC }_{i}+ \\
& \beta_{9} \text { Kom }_{i}+\beta_{10} K_{-} \text {Impor }_{i}+\beta_{11} \text { KSolid }_{i}+ \\
& \beta_{12} \text { nonEU }_{j}+\beta_{13} \text { LnJarak }_{j}+\beta_{14} \text { LnKurs }_{t}+ \\
& \beta_{15} \text { LnGDPCap }_{j}+\beta_{15} \text { nonEU_LnGDPcap }_{j}+ \\
& e_{i j t}
\end{aligned}
$$

Dimana i merupakan indeks dari karakter yang melekat pada produk meliputi skema sertifikasi (SVLK, FSC); jenis kayu (meranti, kayu rimba campuran, kayu komersial tiga, kayu impor dan kayu indah), tipe bahan baku yang digunakan (solid dan non solid). Indeks j merupakan indeks dari negara tujuan ekspor (Non-EU), jarak negara tujuan dan variable interaksi antara variable non-EU dengan GDP perkapita. Sedangkan $\dagger$ adalah indeks dari kurs negara tujuan terhadap USD dan $e_{\mathrm{ijt}}$ merupakan random error. Dalam analisis ini seluruh variabel independen diekspresikan dalam variabel dummy kecuali untuk variabel jarak, nilai tukar dan GDP perkapita. Penggunaan variabel dummy ditujukan untuk mempermudah interpretasi atas atribut dalam jumlah besar dalam spesifikasi model. Dengan memasukkan istilah konstan, parameter diinterpretasikan sebagai persentase penyimpangan dari produk dasar (non sertifikat) dengan seperangkat atribut tertentu.

\section{Pengujian Model}

Analisis data pada study ini akan menggunakan pendekatan antara model efek 
tetap (Fixed Effect Model) atau model efek acak (Random Effect Model). Untuk menentukan pendekatan model terbaik yang di untuk pengolahan data panel terlebih dahulu melalui uji Hausmann test yang merupakan uji untuk mengetahui apakah model fixed effect lebih baik dari model random effect. Hipotesis dari uji ini yaitu: HO: Model Random Effect dan H1: Model Fixed Effect.

Nilai statistik Hausmann akan dibandingkan dengan nilai Chisquare sebagai dasar penolakan HO. Jika nilai X2-statistik hasil pengujian lebih besar dari X2-tabel maka cukup bukti untuk melakukan penolakan pada HO sehingga pendekatan yang digunakan adalah model fixed effect, begitu pula sebaliknya.

\section{Periode Observasi}

Observasi menggunakan data realisasi penerbitan LS Ekspor produk kayu olahan HS 4407 dan HS 4409 selama periode Maret 2006 sampai dengan Maret 2017. Untuk mengestimasi pengaruh sertifikasi SVLK terhadap harga premium digunakan periode tahun 2006 sampai 2012 mengingat setelah 1 Januari 2013 seluruh produk telah berlisensi VLegal. Sedangkan untuk mengestimasi pengaruh sertifikasi FSC digunakan periode 2006 sampai 2017, mengingat FSC merupakan skema voluntary sehingga tidak seluruh produk bersertifikat.

\section{Hipotesis Penelitian}

Dalam penelitian ini, berdasarkan penelitian terdahulu serta didukung teori-teori yang ada dapat disusun hipotesis atas faktor-faktor yang memengaruhi ekspor kayu olahan Indonesia. Adapun hipotesis utama yang diajukan dalam riset ini adalah sebagai berikut:

(1) HO: Sertifikasi SVLK tidak mempunyai pengaruh terhadap harga premium produk ekspor kayu olahan Indonesia;

(2) H1: Sertifikasi SVLK mempunyai pengaruh terhadap harga premium produk ekspor kayu olahan Indonesia;

(3) HO: Tujuan ekspor produk kayu olahan baik EU dan Non-EU memiliki pengaruh yang sama atas harga produk kayu olahan bersertifikat;
(4) H1: Tujuan ekspor produk kayu olahan baik EU dan Non-EU memiliki pengaruh yang sama atas harga produk kayu olahan bersertifikat;

(5) HO: Karakteristik produk kayu olahan meliputi jenis kayu, jenis bahan baku tidak berpengaruh terhadap harga ekspor kayu olahan Indonesia;

(6) $\mathrm{H1}$ : Karakteristik produk kayu olahan meliputi jenis kayu, jenis bahan baku tidak berpengaruh terhadap harga ekspor kayu olahan Indonesia;

\section{HASIL DAN ANALISIS}

\section{Realisasi Ekspor Kayu Olahan Indonesia}

Berdasarkan data LS Ekspor kayu olahan dengan HS 4407 dan 4409 dari tahun 2006 sampai 2017 secara tren menunjukkan adanya peningkatan. Peningkatan ini terjadi tidak hanya dari sisi volume namun juga dari sisi nilai ekspor. Pada periode 2006 - 2008 ekspor volume ekspor kayu olahan sempat mengalami fluktuasi yang cukup tajam, terutama pada tahun 2008. Isu illegal loging yang mencuat atas produk perkayuan Indonesia saat itu disinyalir menjadi salah satu faktor yang mempengaruhi turunnya kinerja ekspor produk kayu Indonesia. Sedangkan mulai tahun 2009, ekspor produk kayu mulai menunjukkan adanya tren peningkatan ekspor.

Tabel 1 Realisasi ekspor kayu olahan periode tahun 2006 sampai dengan tahun 2017

\begin{tabular}{ccr}
\hline Tahun & $\begin{array}{c}\text { Vol Rata-rata } \\
\text { Per Bulan (M3) }\end{array}$ & $\begin{array}{c}\text { Nilai Ekspor Rata- } \\
\text { rata Perbulan (USD) }\end{array}$ \\
\hline $2006^{*}$ & $45,762.96$ & $40,372,883.04$ \\
2007 & $52,823.88$ & $45,285,789.21$ \\
2008 & $19,069.71$ & $16,610,963.19$ \\
2009 & $49,648.01$ & $41,232,560.47$ \\
2010 & $59,235.24$ & $50,976,120.59$ \\
2011 & $55,911.92$ & $48,805,519.77$ \\
2012 & $50,334.88$ & $44,048,593.80$ \\
2013 & $46,276.02$ & $41,047,621.80$ \\
2014 & $58,938.15$ & $51,042,772.52$ \\
2015 & $58,728.96$ & $49,807,055.68$
\end{tabular}




\begin{tabular}{ccr}
\hline Tahun & $\begin{array}{c}\text { Vol Rata-rata } \\
\text { Per Bulan (M3) }\end{array}$ & $\begin{array}{c}\text { Nilai Ekspor Rata- } \\
\text { rata Perbulan (USD) }\end{array}$ \\
\hline $2006^{*}$ & $45,762.96$ & $40,372,883.04$ \\
2007 & $52,823.88$ & $45,285,789.21$ \\
2016 & $60,511.72$ & $52,990,006.65$ \\
$2017^{* *}$ & $58,173.77$ & $48,793,551.06$ \\
Jumlah & $51,284.60$ & $44,251,119.81$ \\
\hline
\end{tabular}

Keterangan:

*) Data periode Maret sampai dengan Desember

**) Data periode Januari sampai dengan Maret

Apabila dilihat berdasarkan nilai rata-rata perbulan selama periode 2008 sampai dengan 2017 baik volume maupun nilai ekspor samasama mengalami kecenderungan peningkatan. Inisiasi pemberlakuan standar legalitas kayu mulai berjalan di tahun 2009 namun demikian sertifikat SVLK baru terbit pertama kali pada semester dua tahun 2010 seiring dengan terakreditasinya lembaga penerbit sertifikat legalitas kayu di Indonesia. Pada awal periode sertifikasi SVLK secara voluntary rata-rata volume ekspor perbulan secara umum mencapai 55.160 M3 meningkat $32 \%$ dibanding rata-rata volume pada periode 2006 - 2009 sebelum adanya sertifikasi legalitas kayu yang hanya sebesar 41.826 M3. Pada periode pemberlakuan SVLK secara mandatory nilai rata-rata volume ekspor secara umum mencapai 56,525 M3 perbulan.

Secara rata-rata harga perkubikasi kayu olahan cukup dinamis selama periode 2006 2017. Harga rata-rata perkubik kayu olahan selama periode ini berada pada kisaran USD 830 sampai USD 890, tanpa membedakan status sertifikasi dan negara tujuan ekspor. Harga rata-rata ekspor kayu olahan sempat mengalami penurunan tajam pada periode 2008 sampai 2009. Namun mulai mengalami kenaikan kembali pada tahun 2010 yang bersamaan dengan mulai berjalannya skema sertifikasi SVLK di Indonesia. Tren menurun kembali terjadi setelah tahun 2013, dimana pada periode ini bersamaan dengan pemberlakuan skema sertifikasi SVLK secara mandatory untuk seluruh ekspor kayu olahan. Dengan tidak adanya perubahan yang fundamental dari sisi kebijakan di sektor kehutanan dan pasar perkayuan selain isu sertifikasi pada saat itu, maka kondisi ini dapat mengindikasikan adanya keterkaitan antara penerapan kebijakan sertifikasi terhadap perubahan harga ekspor kayu olahan Indonesia.

Realisasi ekspor Indonesia $80 \%$ lebih ditujukan untuk pasar di luar Uni Eropa. China masih merupakan tujuan ekspor utama produk kayu olahan Indonesia. Data tahun 2016 menunjukkan bahwa volume ekspor kayu olahan Indonesia ke dunia mencapai 726,14 ribu meter kubik. Sementara impor China tercatat mencapai $29 \%$ dari total volume ekspor kayu olahan Indonesia atau setara dengan 213,54 ribu meter kubik. Kemudian Uni Eropa yang menempati urutan kedua dengan prosentase impor mencapai 19\% serta Jepang dan Australia dengan besaran volume impor masing-masing $12 \%$ dari total volume ekspor.

Sejalan dengan volume ekspor, nilai ekspor terbesar untuk produk kayu olahan Indonesia juga berasal dari negara non-EU. Sebesar 31\% dari nilai ekspor berasal dari China. Sedangkan EU menyumbang $18 \%$ dari total ekspor kayu olahan Indonesia ke dunia. Pada periode pemberlakuan SVLK secara mandatory nilai ekspor rata-rata secara umum mencapai USD 48,7 juta perbulan sedikit lebih tinggi dibanding periode voluntary sebesar USD 47,9 juta. Namun demikian, peningkatan dua periode ini cukup signifikan jika dibandingkan dengan periode sebelum adanya sertifikasi yang hanya mencapai USD 35,8 juta secara rata-rata per bulan. Apabila dibandingkan antara posisi volume dan nilai rata-rata ekspor perbulan periode sebelum sertifikasi terhadap kondisi dua tahun terakhir terdapat peningkatan sekitar 35\% secara umum.

\section{Faktor yang Mempengaruhi Harga Premium}

Riset ini bertujuan untuk mengetahui pengaruh sertifikasi produk kayu olahan terhadap harga menggunakan pendekatan Hedonic Model. Jumlah observasi, nilai mean dan standar deviasi dari tiap variabel uji secara detail sebagaimana tabel berikut:

Tabel 2 Statistik deskriptif variabel uji

\begin{tabular}{clrrc}
\hline No & Variabel & \multicolumn{1}{c}{$N$} & mean & \multicolumn{1}{c}{ sd } \\
\hline 1 & $\mathbf{m}$ & $\mathbf{1 0 9 , 5 1 8}$ & $\mathbf{0 . 3 9 2}$ & $\mathbf{0 . 4 8 8}$ \\
2 & v† & 109,518 & 0.0662 & 0.249 \\
3 & vm & 109,518 & 0.268 & 0.443 \\
4 & FSC & 109,518 & 0.132 & 0.339 \\
5 & Fv & 109,518 & 0.018 & 0.133
\end{tabular}


Aditya Rahman Aziz dan Vid Adrisson, Cendekia Niaga 2021, Volume 5 Nomor 1: hal 84-99

\begin{tabular}{clrrr}
\hline No & Variabel & \multicolumn{1}{c}{$N$} & mean & \multicolumn{1}{c}{ sd } \\
\hline 1 & $\mathbf{m}$ & $\mathbf{1 0 9 , 5 1 8}$ & $\mathbf{0 . 3 9 2}$ & $\mathbf{0 . 4 8 8}$ \\
$\mathbf{6}$ & Fm & 109,518 & 0.0749 & 0.263 \\
7 & Noneu & 109,518 & 0.755 & 0.43 \\
8 & Solid & 109,518 & 0.93 & 0.255 \\
9 & K Indah & 109,518 & 0.158 & 0.364 \\
10 & K Meranti & 109,518 & 0.597 & 0.491 \\
11 & KRC & 109,518 & 0.168 & 0.374 \\
12 & K Kom 3 & 109,518 & 0.0635 & 0.244 \\
13 & K Impor & 109,518 & 0.0144 & 0.119 \\
14 & InGDPcap & 109,518 & 10.58 & 1.272 \\
15 & InPrice & 109,482 & 6.706 & 0.694 \\
16 & Lnjarak & 109,518 & 8.533 & 0.684 \\
17 & noneu_Lngdp & 109,518 & 7.864 & 4.631 \\
18 & Inkurs7an & 109,503 & 7.138 & 2.441 \\
\hline
\end{tabular}

\begin{tabular}{|c|c|c|}
\hline No & Variables & InPrice \\
\hline 1 & $\mathrm{~m}$ & $0.0764^{* * *}$ \\
\hline 2 & $\mathrm{v}+$ & $0.0735^{* * *}$ \\
\hline 3 & $\mathrm{vm}$ & 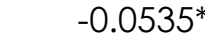 \\
\hline 4 & $\mathrm{fsc}$ & $0.138^{* * *}$ \\
\hline 14 & Inkurs7an & $-0.128^{* * *}$ \\
\hline 15 & Lnjarak & -0.00179 \\
\hline 16 & noneu_Lngdp & -0.0071 \\
\hline \multirow[t]{4}{*}{17} & Constant & $6.942^{* * *}$ \\
\hline & Observations & 109,467 \\
\hline & Number of crossed & 22,184 \\
\hline & R-squared & 0.06 \\
\hline \multicolumn{3}{|c|}{ Robust standard errors in parentheses } \\
\hline & ${ }^{* * *} \mathrm{p}<0.01$, ** $\mathrm{p}<0$ & $0<0.1$ \\
\hline
\end{tabular}

Hasil uji Hausman menunjukkan nilai probabilitas 0.0000 , dimana angka tersebut lebih kecil dari a 0.05. Karena prob $(0.0000)<a(0.05)$, maka cukup bukti untuk melakukan penolakan terhadap HO, sehingga metode yang digunakan adalah fixed effect. Dengan adanya permasalahn multikolinearitas dan heteroskedastisitas pada model maka dalam regresi menggunakan model fixed effect robust.

Hasil regresi pada model menunjukkan bahwa dari seluruh variabel yang diuji 9 variabel memiliki efek yang signifikan terhadap harga ekspor kayu olahan dengan taraf signifikansi a $=0,01$. Sementara variable fm dan LnGDPcap signifikan pada $a=0,05$ dan variable $\mathrm{vm}$ signifikan pada tingkat $a=0,1$. Sedangkan variable LnJarak, noneu_Lngdpcap dan fvt menunjukkan hasil yang tidak signifikan berpengaruh terhadap harga.

\section{Tabel 3. Hasil regresi variable pembentuk dengan metode fixed effect robust}

\begin{tabular}{|c|c|c|}
\hline No & Variables & InPrice \\
\hline 1 & $m$ & $0.0764^{* * *}$ \\
\hline 2 & $\mathrm{v} \dagger$ & $0.0735^{* * *}$ \\
\hline 3 & $\mathrm{vm}$ & $-0.0535^{*}$ \\
\hline 4 & fsc & $0.138^{* * *}$ \\
\hline 5 & $f v t$ & -0.0391 \\
\hline 6 & $\mathrm{fm}$ & $-0.0740 * *$ \\
\hline 7 & solid & $0.216^{* * *}$ \\
\hline 8 & indah & $0.617^{* * *}$ \\
\hline 9 & meranti & $0.323^{* * *}$ \\
\hline 10 & krc & $0.102^{* * *}$ \\
\hline 11 & impor & $0.630^{* * *}$ \\
\hline 12 & noneu & 0.0328 \\
\hline 13 & Ingdpcap & $0.0163^{* *}$ \\
\hline
\end{tabular}

Untuk mengetahui sejauh mana faktor internal dari firm berpengaruh terhadap harga, mengingat tidak terdapat variable karakter firm pada model, maka perlu untuk mengukur tingkat konsentrasi pasar dari produk kayu olahan Indonesia. Pengukuran konsentrasi pasar menggunakan metode Herfindahl Hirchman Index (HHI). Penghitungan $\mathrm{HHI}$ dilakukan dengan menghitung market share dari eksportir kayu olahan Indonesia dengan menggunakan nilai ekspor FOB dari tiap eksportir untuk produk kayu yang dominan yaitu produk kayu olahan berbahan baku kayu meranti solid pada tahun 2016. Penghitungan $\mathrm{HHI}$ menunjukkan bahwa pasar ekspor kayu olahan merupakan pasar yang sangat kompetitif. Besaran $\mathrm{HHI}$ untuk kayu olahan sebesar 0,0126 mendekati angka indeks 0,01 yang menunjukkan pasar yang tidak terkonsentrasi dan sangat kompetitf.

Konsekuensi dari pasar yang kompetitif adalah masing-masing eksportir tidak memiliki kekuatan monopoli atas produk dan harga lebih banyak ditentukan dari mekanisme pasar. Perbedaan karakter dari tiap-tiap firm tidak dapat secara langsung mempengaruhi harga yang terbentuk. Sehingga meskipun ada unobserved variable dalam model bukanlah berasal dari karakter dari industry kayu olahan, dan hal tersebut telah tertangkap pada error term model fixed effect.

\section{Pengaruh Sertifikasi SVLK Terhadap Harga}

Hasil pengujian menunjukkan bahwa sertifikasi SVLK memiliki pengaruh terhadap pembentukan harga produk kayu olahan. Koefisien individual untuk variabel sertifikasi 
SVLK dalam skema voluntary maupun mandatory adalah positif terhadap harga perkubik ekspor kayu olahan Indonesia. Kondisi ini sesuai dengan hipotesis awal (H1) bahwa terdapat pengaruh yang signifikan positif antara sertifikasi SVLK dengan harga ekspor per kubik produk kayu olahan Indonesia. Keberadaan sertifikat SVLK secara rata-rata menunjukkan harga jual $7 \%$ lebih tinggi jika dibandingkan dengan produk kayu olahan yang tidak bersertifikat. Sebagai pembanding untuk produk yang bersertifikat FSC secara ratarata menunjukkan harga jual $13 \%$ lebih mahal dibandingkan dengan produk sejenis nonsertifikat.

Hasil estimasi menunjukkan bahwa penerapan SVLK secara voluntary dan mandatory memberikan efek positif terhadap harga. Secara signifikan sertifikasi SVLK memberikan peningkatan harga menjadi $7,6 \%$ pada periode mandatory. Sementara kondisi pada saat periode voluntary menunjukkan tingkat harga produk sertifikasi sebesar $7,3 \%$ atau $0,3 \%$ lebih murah dibandingkan harga pada saat mandatory.

Namun demikian dengan pemberlakuan sertifikasi secara mandatory ternyata memberikan pengaruh negatif bagi eksportir yang sudah lebih dahulu bersertifikat VLK secara voluntary. Hasil estimasi variabel vm menunjukkan efek yang negatif. Perusahaan yang saat periode voluntary telah bersertifikat SVLK mendapatkan differensiasi harga ratarata sebesar 7,3\% dibanding eksportir lain yang produknya belum bersertifikat. Namun, saat sertifikasi diberlakukan secara mandatory pengaruhnya justru menurunkan tingkat harga sebesar 5\%. Hal ini terjadi karena saat diberlakukan secara mandatory seluruh produk ekspor kayu olahan Indonesia sudah seluruhnya bersertifikat dan menghilangkan kekhususan dari produk. Efek dari kondisi tersebut harga produk mengalami penurunan untuk mendekati harga pasar untuk produk bersertifikat ekolabel yang telah terbentuk.

Besaran produksi dan strategi pemilihan pasar penting untuk dapat mengkompensasi biaya yang dikeluarkan untuk sertifikasi. Sebagai gambaran, rata-rata harga jual permeter kubik untuk kayu olahan non sertifikasi berdasarkan dengan tujuan non-EU pra SVLK sebesar USD 814 per meter kubik. Sedangkan harga setelah bersertifikat mandatory untuk tujuan non-EU rata-rata sebesar USD 819 per meter kubik. Sedangkan untuk pasar EU pra SVLK harga sebesar USD 1.036 per meter kubik dan menjadi USD 1.068 per meter kubik pada saat SVLK mandatory. Biaya pelaksanaan sertifikasi SVLK pada industri perkayuan kapasitas 2.000 dan 6.000 meter kubik per tahun mencapai USD 12.500 untuk skema SVLK setara dengan USD 5,2 - 15,6 per meter kubik (SVLK) bergantung pada unit produksi yang dihasilkan. Artinya bahwa untuk pasar non EU selisih harga produk bersertifikat dan non sertifikat lebih rendah jika dibandingkan pasar EU. Sementara apabila berdasarkan hasil regresi price premium yang terjadi hanya lebih kurang USD 1 per meterkubik $(\operatorname{LnP}=0,076)$. Sementara biaya sertifikasi tetap harus dikeluarkan guna dapat memenuhi ketentuan wajib sertifikasi dari pemerintah. Sehingga masih diperlukan langkah-langkah untuk meningkatkan keberterimaan skema sertifikasi untuk memperluas pasar dan meningkatkan volume ekspor agar dapat mengkompensasai biaya sertifikasi.

\section{Pengaruh Negara Tujuan Ekspor dan GDP Perkapita Terhadap Harga}

Variabel GDP perkapita negara tujuan memiliki nilai probabilitas yang signifikan, $\mathrm{Hal}$ ini menunjukkan bahwa variabel GDP perkapita negara tujuan berpengaruh nyata terhadap harga ekspor kayu olahan Indonesia. Nilai koefisien variabel GDP perkapita negara tujuan adalah 0.016, artinya setiap kenaikan GDP perkapita negara tujuan sebesar satu persen, akan meningkatkan harga perkubik kayu olahan Indonesia sebesar 1,6\% (ceteris paribus). GDP perkapita negara tujuan menunjukkan tingkat daya beli masyarakat, sehingga dengan meningkatnya daya beli masyarakat di negara tujuan akan meningkatkan nilai ekspor kayu olahan Indonesia ke negara tersebut. Semakin tinggi income, masyarakat lebih memiliki preferensi terhadap produk bersertifikat ekolabel.

Hasil estimasi variabel negara tujuan ekspor memiliki pengaruh yang tidak signifikan. Setelah dilakukan kontrol dengan menggunakan variable jarak dan varabel lainnya, tidak terdapat perbedaan harga antara wilayah Uni Eropa dan Non-Uni Eropa. Sedangkan hasil 
interaksi antara variable Non-EU dengan GDP percapita menunjukkan pengaruh yang tidak signifikan. Hal ini menunjukkan bahwa tidak ada perbedaan dampak kenaikan income terhadap harga jual kayu olahan antara EU dan Non-EU.

Pengaruh Kharakteristik Produk (Jenis Kayu dan Tipe Bahan Baku) Terhadap Harga

Komponen karakteristik dari produk kayu olahan baik dari jenis kayu dan tipe bahan baku menunjukkan pengaruh yang signifikan terhadap harga perkubik kayu olahan. Produk yang menggunakan bahan baku dari kayu solid secara rata-rata memiliki harga lebih tinggi $21 \%$ dibandingkan dengan produk kayu olahan berbahan baku kayu engineering. Hal ini dapat dipahami bahwa harga bahan baku kayu solid secara umum lebih tinggi dibandingkan dengan kayu engineering. Keberadaan kayu engineering sendiri salah satunya adalah untuk meningkatkan efisiensi penggunaan bahan baku kayu yang mahal guna meningkatkan nilai tambah.

Sementara itu pemilihan jenis kayu ternyata memiliki pengaruh yang signifikan terhadap harga. Apabila dibandingkan dengan kayu komersial 3, hasil estimasi menunjukkan bahwa penggunaan kayu indah memiliki pengaruh kenaikan harga tertinggi sebesar $61 \%$ terhadap produk dari jenis kayu lainnya. Karakteristik corak yang khusus dari kelompok kayu indah yang menyebabkan harga jual kayu kelompok ini cukup tinggi. Penggunaan kayu dari kelompok meranti berpengaruh meningkatkan harga ekspor produk sebesar 32,5\% dibanding jenis kayu komersial 3 . Kelompok meranti terdiri dari berbagai jenis kayu yang umumnya berasal dari hutan alam yang memiliki kelas kuat dan kelas awet sedang hingga tinggi. Penggunakan kayu kelompok rimba campuran memiliki harga jual perkubikasi sebesar 10\% lebih tinggi dibanding kayu komersial 3, kelompok kayu ini terdiri dari banyak jenis kayu yang memiliki kelas kuat dan awet yang sedang. Sedangkan untuk kayu komersial 3 dalam porsi kecil digunakan untuk kayu olahan mengingat kelompok kayu ini lebih banyak ditujukan sebagai bahan baku pulp dan kertas. Kondisi ini sesuai dengan hipotesis awal bahwa karakteristik kayu akan mempengaruhi harga produk kayu olahan.

\section{KESIMPULAN}

Sertifikasi SVLK berpengaruh terhadap pembentukan harga premium ekspor produk kayu olahan Indonesia. Penerapan skema ini baik secara voluntary maupun mandatory terbukti berpengaruh terhadap harga perkubik ekspor produk kayu olahan Indonesia. Pada periode voluntary, meskipun baru dalam tahap untuk memperoleh pengakuan pasar namun limitasi jumlah eksportir ini memberikan karakteristik produk bersertifikat yang membuatnya terdifferensiasi dari sisi harga. Sedangkan pada periode mandatory SVLK berpengaruh pada kepastian bahwa seluruh produk yang diekspor dari Indonesia bersertifikat SVLK hal ini mendorong harga terdifferensiasi sedikit lebih tinggi.

Meskipun terdapat bukti keberadaan harga premium, namun masih banyak kendala yang dihadapi skema ini. Dalam prakteknya price premium yang terbentuk dari sertifikasi SVLK masih relatif rendah jika dibandingkan dengan biaya yang harus dikeluarkan dalam sertifikasi. Kondisi ini dapat berpengaruh terhadap kinerja ekspor perusahaan berskala kecil dan menengah. Utamanya terkait penambahan biaya produksi untuk mengelola sertifikasi yang telah dimiliki. Di sisi lain lain bagi perusahaan yang bersertifikat lebih awal (periode voluntary) penerapan skema mandatory ternyata berpengaruh menurunkan tingkat harga produk bersertifikat. Hal ini karena tidak ada lagi kekhususan dari produk ekspor dari Indonesia sehingga harga kembali mengikuti harga pasar produk bersertifikat secara umum.

Hasil riset juga menunjukkan bahwa tidak terdapat perbedaan harga antar pasar EU dan Non-EU. Realisasi tujuan ekspor ke wilayah NonUni Eropa tidak berpengaruh terhadap pembentukan harga perkubik ekspor produk kayu olahan Indonesia. Meskipun desain skema SVLK Untuk memenuhi pasar Uni Eropa namun harga yang terbentuk tidak memunculkan tingkat differensiasi yang besar. Kondisi ini menjawab kenapa tren ekspor kayu olahan Indonesia $80 \%$ masih berorientasi pada pasar Non-Uni Eropa. 


\section{REFERENSI}

Aguilar, F. X., \& Cai, Z. (2010). Conjoint effect of environmental labeling, disclosure of forest of origin and price on consumer preferences for wood products in the US and UK. Ecological Economics, $\quad 70(2), \quad 308-316$. https://doi.org/10.1016/i.ecolecon.2010.09.002

Aguilar, F. X., \& Vlosky, R. P. (2007). Consumer willingness to pay price premiums for environmentally certified wood products in the U.S. Forest Policy and Economics, 9(8), 1100-1112. https://doi.org/10.1016/j.forpol.2006.12.001

Astana, S., Obidzinski, K., Fathurrahman Riva, W., Hardiyanto, G., Komarudin, H., \& Sukanda, S. (2014). Implikasi Biaya Dan Manfaat Pelaksanaan Svlk Terhadap Sektor Perkayuan Skala Kecil. Jurnal Penelitian Sosial Dan Ekonomi Kehutanan, 11 (3), 175-198.

https://doi.org/10.20886/jsek.2014.11.3.175-198

Balfas, J. (2016). Penerbit FORDA PRESS Bogor, 2016.

Boampong, E., Production, F., Polytechnic, K., Effah, B., Production, F., Polytechnic, K., ... Polytechnic, K. (2015). Factors influencing the choice of timber for furniture and joinery production in ghana. European Journal of Engineering and Technology, $3(5), 48-59$.

Ginting, A. M. (2013). -1396957338. 7(1), 1-18.

Krugman, P. R., \& Obstfeld, M. (2009). International economics: Theory and policy. Boston: Pearson Addison-Wesley.

Lancaster, K. J. (1966). A New Approach to Consumer Theory Author ( s): Kelvin J. Lancaster Source : The Journal of Political Economy, Vol . 74, No . 2 ( Apr ., 1966 ), pp . 132-157 Published by: The University of Chicago Press Stable URL: http://www.jstor.org/stable/182883. 74(2), 132157.

List, J. A., \& Gallet, C. A. (2001). What experimental protocol influence disparities between actual and hypothetical stated values? Environmental and Resource Economics, 20(3), 241-254. https://doi.org/10.1023/A:1012791822804

Murphy, J. J., Allen, P. G., Stevens, T. H., \& Weatherhead, D. (2005). A meta-analysis of hypothetical bias in stated preference valuation. Environmental and Resource Economics, 30(3), 313-325. https://doi.org/10.1007/s10640-004-3332$\mathrm{z}$

Owari, T., Juslin, H., Rummukainen, A., \& Yoshimura, T. (2006). Strategies, functions and benefits of forest certification in wood products marketing: Perspectives of Finnish suppliers. Forest Policy and Economics, 9(4), 380-391. https://doi.org/10.1016/j.forpol.2005.10.005

Owen, P. D., Ryan, M., \& Weatherston, C. R. (2007). Measuring competitive balance in professional team sports using the Herfindahl-Hirschman index. Review of Industrial Organization, 31 (4), 289-302. https://doi.org/10.1007/s1 1151-008-9157-0

Ozanne, L. K., \& Vlosky, R. P. (1997). Willingness to Pay for Environmentally Certified Wood Products: A Consumer Perspective. Forest Products Journal, 47(6), 39-48.

Prestemon, J. P. (2015). The impacts of the Lacey Act Amendment of 2008 on U.S. hardwood lumber and hardwood plywood imports. Forest Policy and Economics. https://doi.org/10.1016/j.forpol.2014.10.002

Roheim, C. A., Asche, F., \& Santos, J. I. (2011). The elusive price premium for ecolabelled products: Evidence from seafood in the UK market. Journal of Agricultural Economics, 62(3), 655-668. https://doi.org/10.1111/j.1477-9552.2011.00299.x

Rosen, S. (1974). Hedonic Prices and Implicit Markets: Product Differentiation in Pure Competition Author ( $s$ ): Sherwin Rosen Published by: The University of Chicago Press Stable URL: http://www.jstor.org/stable/1830899 JSTOR is a not-for-profit service that helps scho. 82(1), 34-55.

Sedjo, R. A., \& Swallow, S. K. (2002). Voluntary EcoLabeling and the Price premium. Land Economics. https://doi.org/10.2307/3147273

Veisten, K. (2002). Potential demand for certified wood products in the United Kingdom and Norway. Forest Science, 48(4), 767-778.

Yamamoto, Y., Takeuchi, K., \& Shinkuma, T. (2014). Is there a price premium for certified wood? Empirical evidence from log auction data in Japan. Forest Policy and Economics, 38, 168-172. https://doi.org/10.1016/j.forpol.2013.07.002 